\title{
Determinants of Money Demand in Algeria: An Empirical Study Using Cointegration and Error Correction Model
}

\author{
Mohammed Djebbouri ${ }^{1}$, Abdelkarim Mansouri ${ }^{1} \&$ Abderrahmane Tahi ${ }^{1}$ \\ ${ }^{1}$ Finance and Banking Department, Moulay Tahar University, Saida, Algeria \\ Correspondence: Mohammed Djebbouri, Finance and Banking Department, Moulay Tahar University., Saida, \\ Algeria. E-mail: med_djebbouri@yahoo.fr
}

Received: August 25, 2019

Accepted: September 17, 2019 Online Published: September 18, 2019

doi:10.5539/mas.v13n10p78

URL: https://doi.org/10.5539/mas.v13n10p78

\begin{abstract}
This investigation aims primarily to estimate the determinants of the demand function of money in its broad sense, in Algeria during the period 1980-2017. To accomplish this study, Cointegration and Error Correction Model (ECM) have been used. Thus, these tests proved the no stationary of time series which led us to apply the cointegration tests, so in the end we estimate the model with error correction. The results of this estimation show that the importance of determinants of money demand in the short and long term are ordered as follows: real income, the velocity of circulation of money (VM2) in the short and long term, the long-term exchange rate; in the short term its importance diminishes in favor of inflation, which has a decisive effect on the demand for money in the short term. The findings reveal that the money demand function is insensitive to the interest rate, which explains why speculation is generally regarded as a less important reason in Algeria.
\end{abstract}

Keywords: determinants of money demand M2, cointegration, error correction model, Algeria

\section{Introduction}

From the perspective of macro - economics, schools of thought differed in the role and effectiveness of money. A school that marginalizes the role of money and reduces the effects on the course of economic life; however, another school gives great importance to role but with limits. Another different school regards its significant roles for it changes the biggest role in influencing other economic variables. Despite the differences, and during the financial development, the role and effectiveness of money become one of the most important economic phenomena. Further, monetary development becomes one of the most influential fields of economic activity as well. Meanwhile, monetary systems improved from commodity to credit, and then to electronic goods, in the sense, from money whose commodity value represents part of its monetary value to money whose commodity value does not represent the importance of determining its monetary value whether it is money issued by central banks or current accounts in the books of commercial banks of electronic money.

Besides, there are various aspects in which we can scrutinize the impact of money on the economy. One of the most fundamental aspects of modern monetary analysis is the relationship between the demand for money and its determinants which is noted as the demand for money. According to Goldfeld (1994), the relation between the demand for money and its main determinants is an important building block in macroeconomic theories (Goldfeld, 1994).

The demand for money is a variable that contributes to the development of economic policies whose aim is to achieve monetary balance in the economy, to control the behavior of the function of demand for money, the knowledge about determinants, the extent of the impact of each factor determining the nature and its degree. Moreover, stability increases the effectiveness of economic policies that have been followed. Also the stability of the cash demands function and the predictability of the expected changes that may occur on it pave the way for the process of making the basics of monetary policies. Research by Caporale and Gil-Alana (2005) suggests that stability of the money demand function is a prerequisite for formulating an effective monetary policy (Caporale \& Gil-Alana, 2005). The latter seek to adjust the point between money supply and demand in the scope of minimizing monetary turbulence and its negative effectiveness on real output. 


\subsection{Research Problem}

Demand for money function manifests the economic activities and dynamics in any country, and emanates various variables to play an enormous role in the determination of the behavior of demand for money function. Hence, the research question can be stated as:

What are the determinants of demand for money in Algeria in the short and long terms? And how does it respond to its particular variables?

\subsection{Research Hypotheses}

In the short-term and long-term, there is a significant positive relationship between demand for real money balances and real income. Also, there is a significant inverse relationship between demand for real money balances and velocity of circulation of money.

There is a significant inverse relationship between demand for real money balances and inflation rate in short term. Also, there is a significant inverse relationship between demand for real money balances and exchange rate in long- term.

Due to the short financial market caused by a deficiency of financial assets, it is expected that there will be no significant effect of interest rates on demand for money in Algeria.

\subsection{The Significance of the Study}

- To recognize the behavior of the cash demand function and the identification of variables involved in the use of modern econometric methods taking into account their effectiveness in the short and the long terms.

- The importance of the demand for money to the economic decision makers to determine and control the monetary policy, where the task of monetary policy will become more complex due to the instability of the demand for money, then the monetary policy maker will not possess a clear vision, because he may not know the levels of money supply that would be more appropriate.

- The significance of combining the analytical theoretical basis with the modern econometric methods to apply them in measuring demand for money as well as the importance of the duration of study which is expanded thirty eight years $(1980$ - 2017) taking several stages in the Algerian economy. This allows us to determinate the most accurate pattern for the money demand function to achieve economic stability by keeping money supply at levels that accelerate economic growth.

\subsection{The Aim of the Study}

This study aims to estimate and analyze the determinants of demand for money balance in Algeria by means of cointergration analysis method and the Error Correction Model (ECM) during the period of 1980-2017. After that, this research tends to estimates the effects (short and long terms) of explanatory variables on the demand for money.

The identification of short-term and long-term variables enables monetary authorities and monetary policymakers to use effective impact tools to influence monetary equilibrium and real equilibrium in the economy, as Algeria is a developing country that is still suffering from severe difficulties to shape its monetary policy and adjust it to achieve economic development goals.

In this study it's important to know if the demand for money balances in Algeria is determined by the level of interest rates in light of the limited substitution between money and other financial assets.

\subsection{The Outline and the Structure of Research}

This research is split into two main parts. The first part is concerned about theoretical aspect in which the determinants of money demand in monetary theories. This part in itself is divided into four sections. The first section deals with the demand for money from the classical theory. The second section is concerned about the demand for money from the Keynesian view. The third section is about the modern quantity theory of money. The last section is concerned about the neo - Keynesian school (Tobin \& Baumol) in the demand for money. The second part of this research examines the empirical aspect that attempts to estimate the function of demand for money in Algeria during 1980 - 2017 in which the results of the study have been presented and analyzed.

\section{Literature Review}

The various economic schools addressed reasons of the demand for money through inquiry and investigation. These schools were different in pointing out those reasons because it was so difficult, that is, its study relies on the human behavior or behavior of individuals. In this regard, money was of great value to economists through last 
centuries and their studies showed several monetary theories emerged from the economic circumstances they used to live in.

\subsection{Classical Theory of Demand for Money}

Classical thought that the only impact of money was to influence the general price level, the money in the classical concept was a means of exchange, a measure of value and had no other function in the economy.

\subsubsection{Fisher's Quantity Theory of Money}

In his cash demand theory for exchange, Fischer (1911) asserts that the cash function as a method of exchange is based on a mathematical conformance on the basis of which any trade between seller and buyer requires exchange of money for goods, services or securities (Fisher, 1911).. At any point in time, the value of goods, services and securities must be equal to the number of transactions $\mathrm{T}$ at that moment multiplied by the rate of the transaction price $\mathrm{P}$, Thus, the PT value will be equal to the cash flow value of $\mathrm{M}$ cash multiplied by the velocity of the circulation of money $\mathrm{V}$ (or more simply velocity - the average number of times per period that the stock of money changes hands to finance transactions) (Serletis, 2007).. This relationship is expressed as follows (Haddad \& Hallul, 2005):

$$
\mathrm{MV}=\mathrm{PT}
$$

Where:

M: An external factor to be determined by the monetary authorities, V: The velocity of money circulation is considered stable and independent in the short term because it depends on technical factors, P: General Price level, $\mathrm{T}$ : Transaction size

In order to achieve balance in the money market, the demand for money must be equal to the supply of money:

$$
\mathrm{MS}=\mathrm{Md}=\mathrm{M}
$$

The actual amount of money required is therefore determined as follows:

$$
\mathrm{M}^{\mathrm{d}}=\frac{\mathrm{M}^{\mathrm{d}}}{\mathrm{P}}=\frac{1}{\mathrm{~V}} \mathrm{~T}
$$

The equation shows that the real amount of money required is inversely proportional to $\mathrm{V}$ and directly proportional to $\mathrm{T}$.

As long as $\mathrm{T}$ and $\mathrm{V}$ are assumed to be stable, the actual amount of money required will also remain constant and the level of balance will change when there is an increase or decrease in the nominal money supply.

However, Fischer's trading formula suffers from a key T-transaction volume problem, involving all transactions, whether caused by current production, products for previous period, or those resulting from the sale of securities, and due to the large volume of such exchanges, it makes it uneasy to assume that $\mathrm{T}$ is stable even when it is fully used.

Solving this problem, classical economists have focused on the current volume of production, that is, the final procurement included in national expenditure. Hence, replacement of the T transactions by the Y national income, and the Fisher formula has been adapted to take the following form (Koraissa, 1984):

$$
\text { M.V= P.Y }
$$

However, V: The velocity of money circulation under this adjustment is now an indication of the number of annual cash balance traded for the purchase of annual output of goods and services, i. e. the speed at which the cash unit is traded as a part of income.

\subsubsection{Cash Balance Approach of Money (Cambridge Equation)}

The Cambridge School's analysis is based on factors that determine individuals' demand for money in the form of unemployed cash balances. Cambridge School economists such as Alfred Marshall and Pigou cite the development of this theory to include factors such as interest rates, amount of individual wealth, means of procurement facilities, future expectations of interest rates and goods prices, which influence individuals' decisions to retain money in the form of an unemployed, however, they believe that such changes can be stable in terms of the above factors, in the short term, or it can be in the same rate of variation of income of individuals, thus, the demand for real cash balances as the following (Dhia, 2008):

$$
\mathrm{Md}=\mathrm{k} . \mathrm{Y}
$$

Y: Cash income 
$\mathrm{K}$ : The proportionality factor represents a proportion of the income that agents wish to retain in the form of cash.

Starting from the equation: $\mathrm{Ms}=\mathrm{Md}=\mathrm{M}$ with the compensation we get the following equation:

$$
\mathrm{M}=\mathrm{K} . \mathrm{Y}
$$

Marshall refers to an inverse relationship between $\mathrm{Y}$ and $\mathrm{k}$ when the amount of money is assumed to be stable, and when real total income is expressed, the formula is as follows:

$$
\mathrm{M}=\mathrm{k} \text {. P .y }
$$

Pigou considers that individuals retain part of their real resources in the form of liquid cash, representing the purchasing power of settlement of transactions, making payments and reserves, since:

$$
\mathrm{M} / \mathrm{P}=\mathrm{k} \cdot \mathrm{y}
$$

This equation is mathematically identical to the formula "Fisher" since $\mathrm{k}=1 / \mathrm{V}$ is the inversion of the velocity of circulation of money from income.

The cash quantity theory was criticized for several criticisms regarding the theoretical basis on which it was based and the results it drew, the most important of which is the stable the velocity of circulation of money and the stability of the output at its full level.

\subsection{The Keynes' Theory of Demand for Money}

Classical ideas have been prevalent in economic explanations generally and in monetary analysis in particular until before the emergence of the world crisis of recession in 1929. After that, the liquidity preference theory was developed by Keynes during the early 1930's following the great depression with persistent unemployment for which the quantity theory of money has no answer to economic problems in the society (Ogiriki \& Andabai, 2014).

The classics while real income is the only variable that affects the level of liquidity held by individuals and by the price change is money market back into balance in case of imbalance due for example to increase the mass of money by the Central Bank, ' Keynes indicates that there is a variable rate of interest (i) who plays an important role and was instrumental in determining the amount of cash held by individuals, and that in the absence of full employment, the fact that this variable is associated with an inverse relationship with the demand for money for speculative purposes.

However, he agrees in his theory of asking for money with the classical theory of the transactional motive as one of the determinants of the demand for money, but added in his theory the motivation and speculation as important determinants of money demand.

Therefore, the function of the demand for money in "Keynes" should be the following formula (Epaphra, 2017):

$$
\mathrm{m}^{\mathrm{d}}=(\mathrm{M} / \mathrm{P})^{\mathrm{d}}=\mathrm{f}(\mathrm{Y}, \mathrm{i})
$$

The demand for money is related to a direct relationship with real income, while it is related to an adverse relationship with the interest rate (Alseryeti, 2008). Keynes explained that the speed of money circulation is related to the inverse relationship with the demand for money $\mathrm{f}(\mathrm{Y}, \mathrm{i})$. When demand decreases, the velocity of circulation of money increases, and vice versa, and this relationship is not stable but changes with interest rate change (i).

The Keynesian theory has been criticized by a series of criticisms, the most important of which is the assumption "Keynes" that the economy has reached into a liquidity trap, a theoretical and particular situation that the economy may not reach at all, and did not specify the interest rate at which the demand for cash is absolute (Haddad \& Hallul, 2005).

\subsection{The Monetarism and Friedman's Modern Quantity Theory of Money}

After the decline of the money quantity theory of classical economics in the view of school of thought, the Chicago school led by Milton Friedman revived this theory in 1956, theory of demand for money has been modernized (Abdel Moneim \& Al-Issa, 2003).

In order to define the basic parameters of this theory, we refer first that "Friedman" defined it as the equation of transaction as formulated by "Fischer" in its form of income is no more than a definition of the velocity of circulation of money:

$$
\mathrm{V}=\frac{\mathrm{PY}}{\mathrm{M}}
$$

According to Friedman, money can be considered as an asset like other assets, whether securities, real assets, consumer goods, etc. Demand for money, like demand for any goods depends on budgetary constraints and on 
the price of money. For the budgetary constraints (income level), it is determined by the amount of total wealth owned by economic units or by the price of the money, which is determined by the cost of alternative opportunities (Farid \& Hassan, 2000).

Friedman considers that the demand for real cash balances $((\mathrm{M} / \mathrm{P}))$ is a function of the following variables:

1. The cost of keeping money as an alternative asset to other forms of wealth, since the concept of total wealth at Friedman is that it includes the following forms: (Farid \& Hassan, 2000).

- Money as the first determinant of this wealth as a cash asset.

- Financial assets (equity - bonds).

- Real assets (real estate - land - etc.).

- Human capital (energy for action being translated into labor incomes).

This wealth is measured by lost retained earnings in bond interest $\left(R_{b}\right)$, or a profit wasted in the form of dividends $\left(\mathrm{R}_{\mathrm{s}}\right)$, and retained earnings might be lost in the form of a reduction in purchasing power due to inflation, measured by the expected inflation rate or the expected price increased over a period of time and expressed in terms of $\left(\frac{\mathrm{dp}}{\mathrm{dt}} \times \frac{1}{\mathrm{P}}\right)$.

2. Wealth and real income: wealth includes all elements of human and non-human wealth, so Friedman overcomes on the problem of measuring wealth being capitalized on the basis that it represents the current value of real income flown of it as well as it is used in real national income capitalization in interest rate, if our symbol to Real income national is "Yr" and " $I$ " interest rate and total wealth $\mathrm{W}$ symbol is real: $\mathrm{W}=\mathrm{Y}_{\mathrm{r}} / \mathrm{i}$.

3. The ratio between human and non-human wealth is symbolized by the symbol: $(\mathrm{H})$, which is the same person as human wealth. Education, for example, constitutes an investment oriented towards increasing human wealth. This leads to an increase in the expected return of this wealth. The possession of natural assets is a non-human wealth. The ratio changes can lead to the impact on the level of permanent and expected income in the long term. The ratio to the effect on the level of permanent and expected income in the long term, thus, the greater the percentage $(\mathrm{H})$ the greater the real demand for money (Al-Shammari, 1999).

4. Finally, factors that may affect the preferences and choices of the retention of money in comparison with other assets and symbolize this group of factors with the symbol: (U), as changes in the choices of individuals and their preferences to retain money as a result of changes that may occur in the Economic and non-economic such as degree of certainty and geographical movements where they can lead to increased preference of individuals for liquid money (Al-Shammari, 1999). So Friedman's cash-demand function takes the next formula: (Koraissa, 1984)

$$
\frac{M}{p}=f\left(R_{b}, R_{s}, \frac{d p}{d t} \times \frac{1}{p}, Y_{p}, H, U\right)
$$

Where:

$\mathrm{M} / \mathrm{P}$ : The function of the demand for money at Friedman, $\mathrm{R}_{\mathrm{b}}$ : Return on bonds, $\mathrm{R}_{\mathrm{s}}$ : Return on stocks,

$\frac{\mathrm{dp}}{\mathrm{dt}} \times \frac{1}{\mathrm{P}}$ : The rate of inflation (or the expected rate of rise in prices), $\mathrm{Y}_{\mathrm{p}}$ : Permanent or continuous income, $\mathrm{H}$ : The ratio between human and non-human wealth, U: Factors that affect the tastes and preferences of individuals.

The five determinants except the $\left(\mathrm{Y}_{\mathrm{p}}\right)$ of the mentioned function enter in one way or another in determining the level of permanent income and expected ( $\left.Y_{p}\right)$, So Freedman's theory is also called the perpetual Income theory of money demand.

The theory of the real cash balances of Friedman was criticized most in his neglect of the role of interest rate, "Laidler" noted the importance of the role of interest rate as a determinant in the money demand function and considered that "Friedman" adopted incorrect statistical methods, and after several years "Friedman" admitted in 1969 the effect of the interest rate on the cash demand function.

\subsection{New Keynesian Schools in Demand for Money}

Keynes considered that the amount of money required for exchanges can yield a return if it is retained in another form of asset, thereby implicitly indicating the effect of the interest rate as well as income in relation to the 
demand for cash from transaction, but considered that the interest rate effect is weak and has been removed from the Keynesian model, while the effect of the interest rate was limited to the demand for cash only for speculative motives. The contemporary demand for money theories have focused on the fact that the demand for cash for transactions itself depends also on the interest rate, without the need to classify that demand as a demand for transactions or a demand for speculative purposes.

\subsubsection{The model of transactions demand for money}

In this context, William Baumol and James Tobin presented this model as an extension of Keynesian theory in the study of demand for money by relying on the stock theory to demand exchange money based on the fact that demand for money depends on the interest rate on bonds (The expected return), the costs of financial transactions necessary to complete the transactions of the sale and purchase of bonds, as well as that the individual seeks to reduce the cost of maintaining the stock of money for the purpose of transactions held with bonds and "William Baumol" introduced the square root model of the cash stock theory in order to explain the demand behavior on Money while minimizing the cost.

Assuming that there is a fixed cost (b) for transactions resulting from the transfer of bonds with a return to cash balances, and $(\mathrm{k})$ representing the true value of cash bonds each time the transfer takes place. Thus, the total cost of transactions to be borne by the individual (TC) will be as follows: (Al-Jabri, \& Thoueny, 2010)

$$
\mathrm{TC}=\mathrm{b}(\mathrm{Y} / \mathrm{K})+\mathrm{i}(\mathrm{K} / 2)
$$

The first limit represents the cost of the transfer, while the second limit represents the cost of return on the average holding of cash $(\mathrm{k} / 2)$ during the period. By minimizing the transaction cost in relation to $(\mathrm{K})$, we will get the square root law of the optimum real cash balances as follows:

$$
\mathrm{M}^{\mathrm{d}} / \mathrm{P}=1 / 2 \sqrt{2 \mathrm{bY} / \mathrm{i}}
$$

That is, the demand for cash balances for transactional purposes is directly linked to the square root of the transaction size, income or fixed cost of converting bonds into cash, and is inversely correlated with the square root of the opportunity cost of the commodity inventory (i.e. interest rate).

By converting the equation above into the logarithmic formula, we will have the following demand for money function:

$$
\operatorname{Ln} \mathrm{Md} / \mathrm{P}=\mathrm{a}+\mathrm{b} 1 \mathrm{Ln} \mathrm{Y}+\mathrm{b} 2 \mathrm{Ln} \mathrm{i}
$$

b1, b2: constant money demand elasticity in relation with the income $\mathrm{Y}$ and interest rate I respectively.

Therefore, the demand for real cash balances is divided into a component that is inversely aligned with the interest rate and a component that is directly in line with income.

\subsubsection{Tobin's Portfolio Balance Approach to demand for money}

This model goes to the fact that individuals maintain a diversified portfolio of bonds and cash based on adjusting preferences of their return and risk. That is to say, the demand for money is a function of the risk and return offered by money and by the alternative assets that individuals can hold instead of money (Epaphra, 2017).

James Tobin introduced the theory of liquidity preference as a risk-based behavior through analysis (expectancy and variance) and explained the relationship between the demand for cash for liquidity and the interest rate under the "portfolio management theory" at the level of a person's economic behavior aimed at determining the optimum structure to his financial portfolio in case of uncertainty about market interest rate trends and the role that cash plays in its context.

Tobin explains the demand for speculative cash as follows:

$$
(\mathrm{M} / \mathrm{P}) \mathrm{d}=\mathrm{f}(\mathrm{rs}, \mathrm{rb}, \pi \mathrm{e}, \mathrm{W})
$$

Where $r_{s}$ is the expected real return on stock, $r_{b}$ is the expected real return on bonds, $\pi^{\mathrm{e}}$ is the expected inflation rate and $\mathrm{W}$ is real wealth.

The uncertainty of an economic person's perception of future interest rate changes makes monetary assets more secure to ensure that their nominal value is not affected, unlike other financial assets such as bonds whose capital values become volatile. Thus, investment in the form of financial assets yields a risk of loss or profit in capital.

In his model, Tobin began with several assumptions:

-Risk exposure when savings are retained in the form of bonds resulting from the variations of interest rate.

-The return on retention of money is non-existent and is subject to a zero risk, assuming the general level of 
prices is stable.

-Most individuals are risk averse and prefer to retain a certain asset and a low return when it is less risky.

The analysis of variance in this model is an application of the key ideas in portfolio selection theory. Tobin assumed that individuals' utility from their assets. This utility is directly related with the expected yield on bonds and the inverse relationship with the risk of these bonds.

In this case of uncertainty, the investor's behavior will go to the optimum position based on the negative risk balancing with the positive returns of the bond acquisition in the selection of the structure of his financial portfolio in the form of optimum construction between financial and monetary assets.

\section{Research Methodology}

This phase of the study aims at the econometric estimation of the money demand function in the Algerian economy using the cointegration method and the error correction model. We have chosen to conduct the analysis from 1980 to 2017, and the selection was based on the availability of data. The frequency of the data collected was annual, thus providing an adequate exploration of the nature and pattern of the study variables.

The annual time series data has been obtained from international data repositories such as World Bank (wdi.worldbank.org) and the International Monetary Fund (www.imf.org).

\subsection{Independent Variables of the Money Demand Function}

Many developing countries have underdeveloped, undiversified financial markets that lack financial sector instruments and payment technologies such that most transactions involve the use of narrow money (Kumar et al, 2013), so they are limited in their ability to substitute money with financial assets. Therefore, the determinants of money demand in developing countries can be determined by distinguishing between the following variables:

\section{Income level}

Economic theory, as already pointed out, confirms that the demand for money depends on the level of real national income, as real wealth and therefore real national income is a key determinant of long-term demand for money. Hence, individuals increase their cash balances when increasing their incomes, but in proportion less to finance economic transactions. In conclusion, there is a direct relationship between the demand for money and the level of real national income. According to Friedman (1956), money demand function assumes that there is a stationary long-run equilibrium relationship between money balances, real income (Epaphra, 2017).

\section{Velocity of circulation of money}

The velocity of circulation of money is determined by the number of times the monetary unit is used in economic transactions over a certain period of time, and is expressed in relation to the ratio between cash and monetary income (cash Supply) (Al-Naga, 1991) and the speed of cash turnover allows for the determination of the volume of demand for money, as it is related to a reverse relationship with Demand for money, increasing the demand for cash for transactional and speculative purposes to reduce the velocity of circulation of money.

Alternate opportunity cost variables for cash retention:

\section{Inflation}

The rate of inflation is a tax on retention of money, if individuals expect a higher price level in the future and hence a decrease in the purchasing power of money, they will start spending it and acquire goods instead, which means, a decrease in the demand for money, the higher the inflation rate the more the expected return of goods for money, the demand for money is decreasing. There is therefore an inverse relationship between the demand for money and the rate of inflation. Nachega (2001) emphasizes inclusion of the expected rate of inflation in the model especially in the case of developing countries where physical assets represent major hedge against inflation due to undeveloped monetary and financial systems and non-market determined interest rates. (Kipsang, 2013).

\section{Interest rate}

The local interest rate represents the opportunity cost of retaining money. If the interest rate increases, the desire to hold financial assets, such as treasury bills, bonds, etc., and vice versa, increase. Liquidity retention refers to an inverse relationship between the rate of return on financial assets and the demand for real cash balances. The higher the interest rate, the less individuals desire to keep money and vice versa. Consequently, the demand for money is inversely related to the interest rate.

The success of monetary policy depends on the degree of responsiveness of money demand to the interest rate. 
Researchers have often argued that the interest rate does not play a significant role in determining the demand for money in developing countries because of the dearth of financial assets. The issue of whether the interest rate influences the demand for money in developing countries is still controversial in the light of mixed results obtained so far by researchers (Nyumuah, 2017)..

\section{Exchange rate}

Some empirical studies of demand for cash have used variable exchange rates due to its impact on the demand for real cash balances (Augustine \& Shwiffm, 1993). In this regard several of studies from 1970 to 2010 have witnessed the relative importance of the variable nominal exchange rates as well as real exchange rate as determinant of money demand models in developing and developed economies (Sober, 2013). It indicated that it would be preferable to include inflation and exchange rates in economies with high inflation rates, and that the exchange rate could measure the expected rate of decline, and thus the opportunity cost of retaining the national currency versus foreign currency (Bahmani-oskooee \& Shin, 2002; Akinlo, 2006; Dagher \& Kovanen, 2011).

The value of their cash balances will increase in foreign currencies, thus making it a kind of investment, in the light of which there is an inverse relationship between the expectations of individuals about exchange rates and the demand for money.

\subsection{Identification of the Econometric Model}

Based on the previous critical theories and empirical studies, the most important of which are Avouyi-dovi et al (2003), and Bahmani Sahar \& Bahmani-oskooee (2012), the following econometric model can be formulated:

$$
\mathrm{M} / \mathrm{P}=\mathrm{f}\left(\mathrm{Y}_{\mathrm{t}}, \mathrm{TCN}_{\mathrm{t}}, \mathrm{INFL}_{\mathrm{t}}, \mathrm{TINTERET}_{\mathrm{t}}, \mathrm{V} 2_{\mathrm{t}}\right)
$$

Where:

M/P: Demand for real cash balances in $(t)$ period, $Y_{t}$ : Real national income in the period $(t)$, TCN $_{t}$ : The nominal

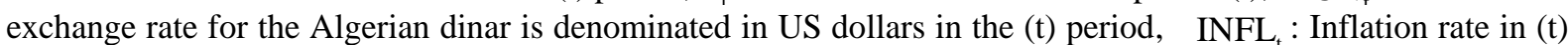
period, TINTERET $T_{t}$ : Nominal interest rate in $(\mathrm{t})$ period, $\mathrm{V} 2_{\mathrm{t}}$ : Money transaction price for quantity of money M2.

This model can be rewritten in logarithmic form as follows:

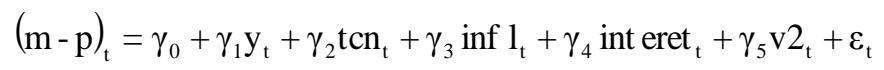

Variables in lowercase letters refer to the logarithm of the model variables.

Where:

$\gamma_{\mathrm{i}}$ : the parameters to be estimated for each independent variable represent the random error term.

\subsection{Descriptive Statistics}

Table 1 presents the descriptive statistics for all variables expressed in natural logarithms of interest in the study over the period of analysis (1980-2017) in Algeria. 
Table 1. Descriptive Statistics of the Variables

\begin{tabular}{ccccccc}
\hline & LM2DIVP & LGDPR & LINF & LINTERET & LVITES & LTCN \\
\hline Mean & 35.25260 & 36.50140 & 1.819607 & 1.283770 & -2.647305 & 3.416159 \\
Median & 35.36724 & 36.17777 & 1.746401 & 1.193629 & -3.375236 & 4.120526 \\
Maximum & 36.85131 & 38.08263 & 3.455359 & 2.079442 & 5.911462 & 4.703838 \\
Minimum & 23.44456 & 33.76442 & -1.081274 & 0.418710 & -7.219730 & 1.344808 \\
Std. Dev. & 2.221497 & 1.095697 & 0.930202 & 0.425595 & 3.011341 & 1.206039 \\
Skewness & -4.139032 & -0.653717 & -0.455874 & 0.503503 & 0.747224 & -0.701231 \\
Kurtosis & 22.33336 & 3.648998 & 4.131023 & 2.767477 & 3.106151 & 1.754693 \\
& & & & & & \\
Jarque-Bera & 700.3164 & 3.373426 & 3.341622 & 1.691200 & 3.554017 & 5.569678 \\
Probability & 0.000000 & 0.185127 & 0.188095 & 0.429300 & 0.169143 & 0.061739 \\
& & & & & & \\
Sum & 1339.599 & 1387.053 & 69.14508 & 48.78325 & -100.5976 & 129.8140 \\
Sum Sq. Dev. & 182.5968 & 44.42041 & 32.01518 & 6.701843 & 335.5224 & 53.81763 \\
Observations & 38 & 38 & 38 & 38 & 38 & 38 \\
\hline
\end{tabular}

Where: LM2DIVP is demand for real money balances; LGDPR is real GDP; LINF inflation rate; LINTERET is interest rate; LVITES is velocity of circulation of money; LTCN is exchange rate of DZ to the USD.

From the table 1, it is found that the mean and median of all the variables are very close in values; this implies that the variables of interest have been stable over the period.

Based on the skewness, the descriptive statistics reveal that real GDP, real exchange and inflation rate are approximately normally distributed because their respective skewness is between -0.5 and 0.5 . The skewness statistics shows that two of the variables- velocity of circulation of money and interest rate are positively skewed, while the remaining three, real GDP, real exchange and inflation rate flow to the demand for real money balances, are negatively skewed.

The results suggest that except demand for real money balances other variables follow normal distribution as represented by Jarque-Bera test and corresponding p-values. The null hypothesis of normal distribution cannot be rejected for the variables at 5 percent level of significance.

\subsection{Studying the Stationary of Study Variables}

One of the conditions for conducting cointegration tests is that the time series are stationary of the same order; otherwise there can be no conintegration between the variables.

As a first step in the applied study, we test the stationary of these variables using the augmented Dicky Fuller test (unit root). Further, in order to test the ADF for each variable, use the OLS method to estimate the three base models for each variable.

$$
\begin{aligned}
& \text { [1] } \Delta \mathrm{x}_{\mathrm{t}}=\rho \mathrm{x}_{\mathrm{t}-1}-\sum_{\mathrm{j}=2}^{\mathrm{p}} \varphi_{\mathrm{j}} \cdot \Delta \mathrm{x}_{\mathrm{t}-\mathrm{j}+1}+\varepsilon_{\mathrm{t}} \\
& \text { [2] } \Delta \mathrm{x}_{\mathrm{t}}=\rho \cdot \mathrm{x}_{\mathrm{t}-1}-\sum_{\mathrm{j}=2}^{\mathrm{p}} \varphi_{\mathrm{j}} \cdot \Delta \mathrm{x}_{\mathrm{t}-\mathrm{j}+1}+\mathrm{c}+\varepsilon_{\mathrm{t}} \\
& \text { [3] } \Delta \mathrm{x}_{\mathrm{t}}=\rho \cdot \mathrm{x}_{\mathrm{t}-1}-\sum_{\mathrm{j}=2}^{\mathrm{p}} \sum_{\mathrm{j}} \cdot \Delta \mathrm{x}_{\mathrm{t}-\mathrm{j}+1}+\mathrm{c}+\mathrm{bt}+\varepsilon_{\mathrm{t}}
\end{aligned}
$$

$\mathrm{ADF}$ is based on the following hypotheses:

$$
\begin{aligned}
& H_{0}=\phi_{j}=1 \\
& H_{1}=\phi_{j}<1
\end{aligned}
$$


Table 2. Results of Unit Root test of the variables of demand for money.

\begin{tabular}{|c|c|c|c|}
\hline \multirow[t]{2}{*}{ Model Variables } & \multicolumn{2}{|c|}{ ADF Extended Vowed Dickey Test for Single Root } & \multirow{2}{*}{$\begin{array}{c}\text { Degree of } \\
\text { cointegration }\end{array}$} \\
\hline & At level & The first difference & \\
\hline \multirow[t]{2}{*}{$(m-p)_{t}$} & $-2.105828^{*}$ & $-5.007634 * *$ & $\mathrm{I}(1)$ \\
\hline & $(0.5232)$ & $(0.0017)$ & \\
\hline \multirow[t]{2}{*}{$y_{t}$} & $-0.522837 *$ & $-5.914525^{* *}$ & $\mathrm{I}(1)$ \\
\hline & $(0.5789)$ & $(0.0001)$ & \\
\hline \multirow[t]{2}{*}{$\operatorname{tcn}_{t}$} & $-1,274238 *$ & $-3.803566 * *$ & $\mathrm{I}(1)$ \\
\hline & $(0.8769)$ & $(0.0286)$ & \\
\hline \multirow[t]{2}{*}{$\operatorname{infl}_{\mathrm{t}}$} & $-2.824072 *$ & $-8.107529 * *$ & $\mathrm{I}(1)$ \\
\hline & $(0.1987)$ & $(0.0000)$ & \\
\hline \multirow[t]{2}{*}{ tinteret $_{\mathrm{t}}$} & $-2.150825^{*}$ & $-6.012692 * *$ & $\mathrm{I}(1)$ \\
\hline & $(0.5009)$ & $(0.0001)$ & \\
\hline \multirow[t]{2}{*}{$\mathrm{v}_{2 \mathrm{t}}$} & $-2.641964 *$ & $-6.191092 * *$ & $\mathrm{I}(1)$ \\
\hline & $(0.2655)$ & $(0.0001)$ & \\
\hline
\end{tabular}

* Accept the hypothesis of the root of the unit at a significant level 5\%,** Reject the hypothesis of the root of the unit at a level of significance $5 \%$.

It is clear from the table above that all-time series of the model variables are nonstationary at the level, where the value of $\mathrm{ADF}(\mathrm{t} . \varnothing \mathrm{j})$ is greater than the critical table values at the level of $1 \% ; 5 \% ; 10 \%$, and acceptance of the null hypothesis $\mathrm{H}_{0}: \varphi_{\mathrm{j}}: 1$, when the same test was applied to the first differences on the series, it became stationary and integrated of order 1 . Thus, these variables could be cointegrated in the money demand function.

\subsection{Cointegration Test for Johansen and Juselius}

After ensuring that all the variables of the study are cointegrated in the same order, then the Johansen and Juselius (1990) multivariate test of co-integration of the test can enable a long-term relationship between the study variables (if there are more than two variables) Two tests are proposed: $-\lambda$ trace and the Maximal eigenvalue $-\lambda$ max test, where:

$$
\begin{aligned}
& \lambda_{\text {trace }}=-\mathrm{n} \sum_{\mathrm{i}=\mathrm{r}+1}^{\mathrm{k}} \ln \left(1-\hat{\lambda}_{\mathrm{i}}\right) \\
& \lambda_{\text {Max }}=-\mathrm{n} \ln \left(1-\hat{\lambda}_{\mathrm{r}+1}\right)
\end{aligned}
$$

Before applying the test the optimal lag length $(\mathrm{P})$ is determined in the Vector Auto regression model by relying on the SC (Schwarz) and AIC (Akaike) standard and in addition to the standard (Log likelihood), for several values (p), the optimal lag length is $(\mathrm{P}=2)$.

The vector auto regression model $(\mathrm{P})$ is formulated as follows:

$$
X_{t}=A_{0}+A_{1} X_{t-1}+A_{2} X_{t-2}+\ldots \ldots \ldots . . . A_{p} X_{t-p}+U_{t}
$$

A0: Vector Constants (KX1).

Ai: Parameters matrix (KXK).

Ut: White noise Vector (Kx1).

The table below summarizes the results of co-integration test for the money demand function variables. 
Table 3. Results of cointegration test for the money demand function variables.

\begin{tabular}{|c|c|c|c|c|}
\hline \multicolumn{5}{|c|}{ Unrestricted Cointegration Rank Test (Trace) } \\
\hline Hypothesized & Eigenvalue & Trace Statistic & 0.05 & Prob.** \\
\hline No. of $C E(s)$ & & & Critical Value & \\
\hline None * & 0.765573 & 133.0437 & 95.75366 & 0.0000 \\
\hline Atmost $1^{*}$ & 0.592903 & 82.27230 & 69.81889 & 0.0037 \\
\hline Atmost $2 *$ & 0.548013 & 50.81768 & 47.85613 & 0.0257 \\
\hline Atmost 3 & 0.323445 & 23.02409 & 29.79707 & 0.2449 \\
\hline Atmost 4 & 0.178812 & 9.348110 & 15.49471 & 0.3342 \\
\hline Atmost 5 & 0.067686 & 2.453012 & 3.841466 & 0.1173 \\
\hline
\end{tabular}

Trace test indicates 3 cointegrating eqn(s) at the 0.05 level

*denotes rejection of the hypothesis at the 0.05 level

**MacKinnon-Haug-Michelis (1999) p-values

The conditions of the validity of cointegration require the stationariness of residuals of the cointegration regression $\left(\varepsilon_{\mathrm{t}} \rightarrow \mathrm{I}(0)\right)$. As the ADF has been used; the test results proved Stationary variable residues, as the absolute value of tQj statistic is greater than the critical value at a 5\% morale level.

Table 4. ADF test results for unit root on cointegration residues

Null Hypothesis: RESID01 has a unit root

Exogenous: Constant, Linear Trend

Lag Length: 0 (Fixed)

\begin{tabular}{|c|c|c|}
\hline Prob.* & & t-Statistic \\
\hline Augmented Dickey- & est statistic & -9.615500 \\
\hline 0.0000 & & \\
\hline Test critical values: & $1 \%$ level & -4.226815 \\
\hline & $5 \%$ level & -3.536601 \\
\hline & $10 \%$ level & -3.200320 \\
\hline
\end{tabular}

The structural change tests of the CUSUM cumulative test and the CUSUMSQ cumulative test confirm that the parameters are stable throughout the study period, ie, that there is no structural change, and show the stability and consistency of the long-term parameters with the short-term parameters, which means the stability of the demand function for cash balances in a broad sense.

- The following results are obtained from Table 2:

Hypothesis (1):

$\mathrm{r}=0$ The calculated value $\lambda_{\text {Trace }}$ of Trace (133.043) is greater than the critical value at $5 \%$, with a value of 95.75366, thus the matrix rank is not equal to zero indicating a cointegration relationship.

Hypothesis (2):

$r=1$ The calculated value (82.2763) is greater than the critical value at the level of $5 \%$, with a value of 69.8188 , from which the rank of the matrix is greater than one, so there is more than one vector for cointegration.

Hypothesis (3):

$r=2$ the calculated value (50.8176) is greater than the critical value at $5 \%$, with a value of 47.8561 , from which there is a co-integration relationship.

The above results illustrate the existence of three cointegrative relationships. We will examine all possible cases in order to determine these relationships using the Engle and Granger method.

After conducting stability tests on the residuals of the cointegration of each pair of integrated study variables, the results showed the direction of the co-integration relations as follows: 
- The existence of a cointegration relationship between demand for real cash balances and real national income $[\mathrm{y}(\mathrm{m}-\mathrm{p})]$

- The existence of a cointegration relationship between demand for real cash balances and the nominal exchange rate $[\mathrm{tcn} \bullet(\mathrm{m}-\mathrm{p})]$;

- There is a cointegration between the demand for real cash balances and the velocity of circulation of money $[\mathrm{v} 2 \varsigma(\mathrm{m}-\mathrm{p})]$.

\subsection{Results of the Estimation of the Long-Term Equilibrium Relationship}

After estimating the model in the OLS method, we get the following results:

$$
\begin{aligned}
(\mathrm{m}-\mathrm{p})_{\mathrm{t}}= & -16,024+1.4077 \mathrm{y}_{\mathrm{t}}-0.295 \inf \mathrm{l}_{\mathrm{t}}+0.856 \text { tinteret }_{\mathrm{t}}-1.31 \mathrm{tcn}_{\mathrm{t}}-1.4462 \mathrm{v} 2_{\mathrm{t}}+\mathrm{e}_{\mathrm{t}} \\
& (-1.4579) \quad(4.8005)^{* * *}(-1.0867) \quad(1.6503) \quad(-4.3108)^{* * * *}(-10.7413)^{* * * * *}
\end{aligned}
$$

$$
\mathrm{R}^{2}=0.84 \quad \mathrm{~F}=33.874
$$

*** Significance at the level of $1 \%$.

Although the explanatory power of the model is high and statistically acceptable, some variables were statistically insignificant (inflation rate, nominal interest rate). This result is consistent with applied studies on developing countries (Valadkhani \& Alauddin, 2003). In these countries, due to lower levels of income, demand for money is reduced for speculative purposes, and the effect of the interest rate on demand for money is less. On the other hand, because of the lack of financial assets offered by the financial market, the possibility of substitution between money and financial assets remains limited, in addition to the high cost of transactions in the financial markets of developing countries, less attractive financial assets where individuals tend to often retain their wealth in the form of money.

The study (Ozturk \& Acaravci, 2008) about eight developing countries in transition also found that there was no long-term interest rate effect on the demand for money.

In this context, the increased degree of financial reforms undertaken by developing countries, including the Algerian economy, would lead to an increase in the interest rate representation of the opportunity cost, as one of the long-term explanation of the demand for money.

The non-response of demand for money to the long-term change in inflation in this study cannot diminish the notion of a strong overall correlation between demand for money and the expected rate of inflation in developing countries. However, some studies have indicated that inflation is not significant in demand for money. For example, the Tang study (2007) of five Asian countries during the period 1960-2005 found a relationship between demand for M2 extended money and inflation in only three of the group countries -Singapore, the Philippines and Malaysia- while the study found no cointegration between money and inflation in both Thailand and Indonesia(Tang, 2007).

The estimate showed that the effect of real income has a positive impact on the demand for money and is significant at 5\% level as the increase in the level of income increases the volume of transactions and demand for liquid assets, although it is highly flexible; that is, the increase of real income by $1 \%$ increases the demand for money by $1.407 \%$ in the long term. Hence, the increase in income increases the desire to retain money as a form of wealth, increase the money allocated to transactions, as well as increase cash balances in reserve, which corresponds to economic theory.

The results showed that the exchange rate change has an adverse effect on the demand for real cash balances at $1 \%$ significance level, with the exchange rate increase of $1 \%$ reducing the demand for cash in local currency by a ratio of $1.31 \%$ in the long term.

The impact of the velocity of circulation of money in Algeria as described in the model results is about 1.44 and its negative signal indicates the inverse relationship between the demand for real cash balances and the velocity of money, which means that the high rate of velocity of money by $1 \%$ reduces the demand of individuals for the balance real cash at a rate of $1.44 \%$ in the long term and has a significance level at $1 \%$.

\subsection{Estimating the Two-Step Error Correction Model for Engel and Granger}

If we have no stationary and cointegrated series of the same order, we must assess their relationships through an error correction model (ECM). Both Engel and Ganger (1987) explain that all integral variables reflect a long-term equilibrium relationship that can be represented by a model (ECM).

Here we present the model estimation method (ECM) in two stages: 
Phase 1: Estimation of the model by the method of "OLS" in the long term

$$
(\mathrm{m}-\mathrm{p})_{\mathrm{t}}=\gamma_{0}+\gamma_{1} \mathrm{y}_{\mathrm{t}}+\gamma_{2} \mathrm{tcn}_{\mathrm{t}}+\gamma_{3} \text { inf } 1_{\mathrm{t}}+\gamma_{4} \text { tint eret }_{\mathrm{t}}+\gamma_{5} \mathrm{v} 2_{\mathrm{t}}+\varepsilon_{\mathrm{t}}
$$

Phase 2: we estimate the relationship of the dynamic model (short term) and this by means of the method "OLS" and symbolizes (ET) where:

$$
\mathrm{E}_{\mathrm{t}}=(\mathrm{m}-\mathrm{p})_{\mathrm{t}}-\left(\widehat{\gamma}+\widehat{\gamma}_{1} \mathrm{y}_{\mathrm{t}}+\widehat{\gamma}_{2} \mathrm{tcn}_{\mathrm{t}}+\widehat{\gamma}_{3} \inf \mathrm{l}_{\mathrm{t}}+\widehat{\gamma}_{4} \mathrm{tint}_{\mathrm{eret}}+\widehat{\gamma}_{5} \mathrm{v} 2_{\mathrm{t}}\right)
$$

It is called an error correction term and is added as a independent variable and lag for one period in the short-term relationship model along with the differences of other no stationary variables, and the model is estimated by the "OLS" method in one stage:

$$
\begin{aligned}
& \Delta(\mathrm{m}-\mathrm{p})_{\mathrm{t}}=\mathrm{b}_{0}+\sum_{\mathrm{i}=1}^{\mathrm{n}} \mathrm{b}_{1 \mathrm{i}} \Delta(\mathrm{m}-\mathrm{p})_{\mathrm{t}-1}+\sum_{\mathrm{i}=0}^{\mathrm{n}} \mathrm{b}_{2 \mathrm{i}} \Delta \mathrm{y}_{\mathrm{t}-1}+\sum_{\mathrm{i}=0}^{\mathrm{n}} \Delta \mathrm{tcn}_{\mathrm{t}-1}+\sum_{\mathrm{i}=0}^{\mathrm{n}} \Delta \inf 1_{\mathrm{t}-1}+\sum_{\mathrm{i}=0}^{\mathrm{n}} \Delta \mathrm{tint} \operatorname{eret}_{\mathrm{t}-1} \\
& +\sum_{\mathrm{i}=0}^{\mathrm{n}} \Delta \mathrm{v} 2_{\mathrm{t}-1}+\alpha \mathrm{E}_{\mathrm{t}-1}+\varepsilon_{\mathrm{t}}
\end{aligned}
$$

Where $(\Delta)$ refers to the first differences of the studied variables and the $\alpha$ coefficient of return to equilibrium, and it must be negative but if not, we reject the existence of the error correction model (ECM).

By applying the two-step error correction model with the lag period of errors correction term next to the differences of other non-stationary variables ( $\Delta$ the demand for real balances is lag for one period $\left.\left.\Delta(\mathrm{m}-\mathrm{p})_{\mathrm{t}-1}\right)\right), \Delta$ Nominal rate of interest $\left(\Delta \mathrm{tint}_{\mathrm{eret}}\right)$, and $\Delta$ nominal exchange rate $\left(\Delta \mathrm{tcn}_{\mathrm{t}}\right)$, and by the statistical deletion of insignificant variables, the following estimated model was reached:

$$
\begin{aligned}
& \Delta(\mathrm{m}-\mathrm{p})_{\mathrm{t}}= 0.0075+1.4882 \Delta \mathrm{y}_{\mathrm{t}}-0.3201 \Delta \mathrm{infl}_{\mathrm{t}}-1.3117 \Delta \mathrm{v} 2_{\mathrm{t}}-0.8067 \mathrm{E}_{\mathrm{t}-1} \\
&(0.0799) \quad(11.0279)^{* * *}(-2.2745)^{* * *} \quad(-17.1542)^{* * * *}(-7.3582)^{* * * *} \\
& \mathrm{R}^{2}=0.93 \quad \mathrm{~F}=121.998
\end{aligned}
$$

*** Significance at the level of $1 \%$, ** significance at the level of $5 \%$.

The results of the error correction model show that there is a short-term dynamic relationship between demand for real cash balances in the Algerian economy and between real national income, inflation rate and the velocity of circulation of money.

We note the significant error correction (ET) at $1 \%$ with the expected negative signal, which also confirms the existence of a long-term equilibrium relationship, which supports the results of the co-integration relationships.

The value of the error correction term coefficient (0.80-) indicates that the demand for real cash balances is adjust to its equilibrium value in each period of time with a ratio of the remaining balance of the period (t-1) equal to $80 \%$, that is, when the demand for real cash balances deviates during the short term in the period (t-1) for its long-term equilibrium value, the equivalent of $80 \%$ of this deviation or imbalance is corrected in the period (t), and on the other hand, this correction ratio reflects the high velocity of adjustment towards equilibrium.

We note from the estimated model that the estimated parameters of the variables (real income, inflation rate and money turnover) are statistically significant at level 1\%, and have the expected signs and in accordance with economic theory, i.e. the demand for real cash balances is directly affected by income and inversely at the rate Inflation and the velocity of circulation of money, that the elasticity of demand for real short-term cash balances was equivalent to 1.488 for real income and was 0.32 for inflation and 1.31 for the velocity of money circulation.

The increase in real income in one unit leads to an increase in the demand for real cash balances by $1.488 \%$, i.e., the response rate is high and sensitive to the change in real income. This confirms that income is one of the most important factors affecting demand for money; the negative effect of the inflation rate reflects the opportunity cost, as its increase reduces the amount of money demand, as a result of the tendency of individuals to get rid of the money they hold and replace them with in-kind assets, their prices are rising because of the risk of erosion of their purchasing power during the inflationary waves. The increase in the rate of inflation by one unit makes the demand for real cash balances decease by $0.32 \%$. Velocity of money circulation has been found to be counterproductive. A one-unit increase reduces demand for real cash balances by $1.4 \%$, which is consistent with economic theory. The faster the turnover of money, the shorter the period of retention of individuals by cash balances. 


\section{Conclusion}

This study has aimed at estimating the determinants of money demand in Algeria using the cointegration analysis technique and the error correction model, during the period (1980 - 2017). Based on the conceptual theorizing input to the subject of research, the study reviewed the most important monetary theories concerning the determinants of demand for money, where the views of these Theories are somewhat different, but this can be explained by the different time periods and the economic and social circumstances that surrounded the, of each theory, which is sufficient reason to make their results different.

In the estimation of the determinants of demand for money in Algeria and after several attempts, it has become clear that the variable of income, the velocity of money circulation and the variables of the cost of the alternative opportunity to retain money have been the most appropriate determinants of demand for money as well as their signs are corresponded to the assumptions of economic theory. The results of the tests for a cointegration of model have showed that there is a relationship of balance in a long-term between the demand for money and its determinants, especially in the Johansen-Juselius and the Angel-Granger method, which have shown a cointegration in a long- term between demand for money and real national income, the nominal exchange rate and the velocity of circulation of money.

In the light of these tests, the error correction model has been estimated in the Angel-Granger method, and the results of the error correction model have showed that there has been an error correction mechanism in the model as the deviations in the demand for money would be corrected annually by $80 \%$ and have reflected a high speed of adjustment towards balance. The estimates have revealed that there has been a cointegration in the short term between the demand for money and real national income, the rate of inflation and the velocity of circulation of money.

The results of the estimation showed that real income is the most important determinant of short-term and long-term cash demand, followed by velocity of money in the short-term and the long-term and long-term exchange rate, while its importance in the short term is declining in favor of inflation, which is reflected as a demand-for-money determinant in the Short-term.

It should also be noted that the use of the interest rate as a determinant of the demand for money has not shown a significant effect in the model and this may reflect the weak substitution between money and financial assets in developing countries, particularly in the Algerian economy, due to the lack of financial assets offered by the financial market as well as the lower level demand for cash in speculative purposes.

There have been some recent studies that examined the relationship between money demand and interest rates in developing countries. Using data from the Philippines, Patalinghug J.C. (2017) investigated the long-run and the short-run relationship between money demand and interest rates in the Philippines by employing quarterly data from first quarter of 1994 up to the third quarter of 2015. An error correction model is estimated to see the effects of output and interest rates on money demand. The results show that the coefficients for 91-day Treasury Bill rates are negative and insignificant. However, the coefficients for 364-day Treasury Bill rates are negative and significant suggesting that they may be better predictors of money demand as opposed to 91-day rates (Patalinghug, 2017).

Maravić and Palić (2005) analyze the long-term and short-term money demand in Serbia for the period January 1996 to March 2005 using Johansen cointegration technique and VECM. As an indicator of the real demand for money they used real M1. The cointegration analysis shows that there is a strong cointegration relationship between real money, overall economic activity, inflation and interest rate on deposits in denar. Short-term model (ECM) shows that the most important determinant of real money demand is inflation and exchange rate. The analysis has proved that the interest rate on deposits in denar, is statistically insignificant determinant and does not have significant role in money demand (Farazmand, 2015).

Concerning panels of countries, Nyumuah (2017) used an error correction models to examine the demand for money for a panel of eight African countries. The study finds the interest rate to be inelastic in the short run but elastic in the long run. This finding suggests that monetary policy is ineffective in developing countries in the long run (Nyumuah, 2017).

\section{Recommendations}

-There is a great importance in identifying variables affecting the long-and short term demand for cash, since the identification of these variables is a significant condition for the success of monetary policy, that is, it enables monetary authorities and monetary policy makers to create a match between money supply and demand by setting the target growth rate for cash that corresponds to the demand for it in the context of reducing monetary 
disturbances and their negative impact on real GDP.

-The results showed that the representation of the nominal exchange rate of the alternative opportunity cost in the Algerian economy has increased as one of the determinants of the long-term demand for money, therefore, it must be emphasized that monetary authorities should take into account the effect of the Algerian dinar exchange rate on the economy when preparing the policy cash.

- According to the econometric results, the interest rate variable in the money demand function is unimportant and weak and this confirms that the monetary authorities in Algeria cannot manage the money supply through only the interest rate channel as a monetary policy instrument, so the importance of using and developing Islamic banking tools after they were accepted by Algerian society.

- The importance of the development of financial markets and the improvement of their efficiency and depth by increasing the extent of financial reforms by enacting the necessary laws, speeding up the licensing of financial intermediaries and encouraging the establishment of financial advisory centers, which will have a positive impact enhancing the confidence of the local and foreign dealers in markets, and thus will be reflected in the increase in market activity and the increase of its financial dealers.

\section{References}

AbdelMoneim, N. \& Al Issa, S. (2003). Money, Banks and Financial Markets. Jordan: Dar Al Hamed, 255-256.

AbdelRazzak, Q. \& Ahmad Al-Ali. (2010). Investment Management and Investment Portfolio. Syria: Damascus University, 65-66.

Al-Jabri, Q. \& Falah Hassan Thoueny. (2010). Monitor changes in the demand for money during banking crises using cointegration models (Co integration Models) (Empirical Study on the banking crisis of South East Asia,.Journal of Administration and Economics, O(80), 90-92. https://www.iasj.net > iasj

Akinlo, A. (2006), The Stability of Money Demand in Nigeria: An Autoregressive Distributed Lag Approach, Journal of Policy Modeling, 28(4), 445-452. https://doi.org/10.1016/j.jpolmod.2005.09.001

Al-Naqa, A. A. (1991). Theory of Money, Banks and Financial Markets. Alexandria University: Youth Association of the University, 248-250.

Alseryeti, N. (2008). Economic Theory. Alexandria University: The University House for Publishing, 71-73.

Al-Shammari, N. M. (1999). Money, Banks and Monetary Theory. Jordan: Zahran Publishing House, 380-382.

Augustine, C. A. \& Shwiff, S. (1993). Cointegration, Real Exchange Rate and Modeling the Demand for Broad Money, Applied Economics, 25(6), 717-726. https://doi.org/10.1080/00036849300000124

Avouyi-Dovi (2003). Estimation of a Currency Demand Function for the Euro Area: A Synthesis of the Results. Banque de France Bulletin, 47-48. www.banque-france.fr

Bahmani-Oskooee. \& Shin, S. (2002). Stability of the Demand for Money in Korea. International. Economic Journal, 16(2), 85. https://doi.org/10.1080/10168730200000015

Bahmani, S. \& Bahmani-Oskooee, M. (2012). Exchange rate volatility and demand for money in Iran, international Journal of Money and Finance, 5(3). https://doi.org/ 10.1504/IJMEF.2012.049048

Caporale, G. M. \& Gil-Alana, L.A. (2005). Fractional cointegration and aggregate money demand functions. The Manchester School, 73(6), 737-753. http://doi.org/10.1111/j.1467-9957.2005.00475.x

Dagher, J. \& Kovanen, A. (2011). On the Stability of Money Demand in Ghana: A bound testing approach. IMF Working Papers, 11/273. https://doi.org/10.5089/9781463925284.001

Dhia, M. (2008), Monetary Economies and Banks, Alexandria University: Youth Association of the University, 40-46.

Epaphra, M. (2017). An Econometric Analysis of Demand for Money and its Stability in Tanzania. Turkish Economic Review, 4(2).

Farazmand, M. M. (2015), Determinants of Money Demand: Evidence from MENA, European Journal of Business and Management, 7(22). https://doi.org/10.7176/EJBM

Farid, M. \& Hassan, S. A. (2000). Money and Economic Balance. Egypt: Shabab Publishing Association.

Fisher, I. (1911). The Purchasing Power of Money: Its Determination and Relation to Credit, Interest and Crisis. New York: Macmillan. 
Goldfeld, S. (1994). Demand for money: empirical studies. In the New Palgrave Dictionary of Money \& Finance. Edited by P. Newman, M. Milgrate and J. Eatwell. London: Macmillan Press.

Haddad, A. \& Hallul, M. (2005). Money and Banks Analytical and Theological Entrance. Amman: Dar Wa'il, First Edition, 116-117.

Kipsang, B. J. (2013). Determinants of Money Demand in Kenya (Master', University of Nairobi, Kenya) Retrieved from https://pdfs.semanticscholar.org

Koraissa, S. T. (1984). Money and Banks. Lebanon: Dar Al-Nahda Al-Arabia, 247-250.

Kumar, S., Don, J.W. \& Fargher, S. (2013). Money demand stability: a case study of Nigeria. Journal of Policy Modeling, 35(6), 978-99. https://doi.org/10.1016/j.jpolmod.2013.03.012

Nyumuah, F. S. (2017). An Investigation into the Interest Elasticity of Demand for Money in Developing Countries: A Panel Data Approach. International Journal of Economics and Finance, Canadian Center of Science and Education, 9(3). https://doi.org/10.5539/ijef.v9n3p69

Ogiriki, T. \& Andabai, P. (2014). Liquidity Preference Theory: A Comparison of William Baumol's and James Tobin's Propositions. An International Multidisciplinary Journal, Ethiopia, 8(4). http://.doi.org/10.4314/afrrev.v8i4.12

Ozturk, I. \& Acaravci, A. (2008). The Demand for Money In Transition Economies, Romanian. Journal of Economic Forecasting, 9(2), 35-43.

Patalinghug, J. C. (2017). An Investigation into the Sensitivity of Money Demand to Interest Rates in the Philippines; Journal of Applied Business and Economics, 19(1). https://doi.org/10.33423/jabe.v19i1.695

Serletis, A. (2007). The Demand for Money: Theoretical and Empirical Approaches, (2nd ed.). New York NY: Springer Science+Business Media, 90.

Sober, M. (2013). Estimating a function of real demand for money in Pakistan: An application of bounds testing approach to cointegration. International Journal of Computer Application, 79(5), 32-50, https://doi.org/10.5120/13740-1548

Tang, T. C. (2007). Money demand function for Southeast Asian countries, Consulting Journal of Economic Studies, 34(6), 476-496. https://doi.org/10.1108/01443580710830952.

Valadkhani A. \& Alauddin, M. (2003). Demand for M2 in Developing Countries: An Empirical Panel Investigation. Discussion Paper, 149, Queensland University of Technology.

\section{Copyrights}

Copyright for this article is retained by the author(s), with first publication rights granted to the journal.

This is an open-access article distributed under the terms and conditions of the Creative Commons Attribution license (http://creativecommons.org/licenses/by/4.0/). 